January 2014

\title{
Linking literacy and libraries in global communities
}

Shelley Jones

Aga Khan University, shelley.jones@aku.edu

Follow this and additional works at: http://ecommons.aku.edu/eastafrica_ied

Part of the Information Literacy Commons

\section{Recommended Citation}

Jones, S. (2014). Linking literacy and libraries in global communities. Journal of Multilingual and Multicultural Development, 35(7), 756-758.

Available at: http://ecommons.aku.edu/eastafrica_ied/24 


\section{Journal of Multilingual and Multicultural Development}

\section{Linking literacy and libraries in global communities}

\section{Shelley Jones}

To cite this article: Shelley Jones (2014) Linking literacy and libraries in global communities, Journal of Multilingual and Multicultural Development, 35:7, 756-758, DOI: 10.1080/01434632.2014.909114

To link to this article: http://dx.doi.org/10.1080/01434632.2014.909114

册 Published online: 14 Apr 2014.

Submit your article to this journal $\pi$

Џlll Article views: 160

Q View related articles $₫$

View Crossmark data \lceil

4 Citing articles: 1 View citing articles 진 
Namibian children. The total cost was about US\$12,333, but what other project - in Africa or elsewhere - can claim to have reached almost every child in the country with reading materials in the children's own languages - as well as English?

There are 24 contributions in total, and 28 contributors, 22 of whom are Africans. The continent is quite well-represented through reports from 11 countries. That said, East Africa is slightly overrepresented; half of the chapters write about literacy in this region, but this is not surprising considering that the conference that led to this volume was held in Kampala. The overall impression is that Reading in Africa, Beyond the School speaks to practitioners as much as it does to academics, and is written in lucid prose. If anything, some of the chapters are a bit too short to fully develop their argument, as 300 pages divided by 24 chapters does not give much space for each article. The benefit of this is the variety and broad scope of this edited volume, and it certainly offers insight into the numerous ways in which reading in Africa can take place beyond the school.

http://dx.doi.org/10.1080/01434632.2014.909113

Espen Stranger-Johannessen Department of Language and Literacy Education University of British Columbia, BC, Canada espensj@gmail.com

(C) 2014, Espen Stranger-Johannessen

Linking literacy and libraries in global communities, by Marlene Asselin and Ray Doiron, Farnham, Ashgate, 2013, xvii + 155 pp., US\$88.00 (hardback), ISBN 978-1-4094-5284-3

Merging global forces of knowledge, information, communication, economics and technology is resulting in the necessity for people everywhere to acquire a range of literacies and capabilities to engage with the world from an empowered disposition. Understanding the ways in which libraries such as the ones considered in this book can best facilitate literacy and learning is crucial. This book by Marlene Asselin and Roy Doiron, intended for those interested in learning more about small libraries on the forefront of bringing about social change, showcases 11 community libraries in marginalised communities from developing, transitional and developed countries. Asselin and Doiron consider the central role these libraries play not only in meeting the diverse literacy and learning needs of their communities, but also in facilitating empowerment, social justice, and social and economic development.

In Chapter 1, Asselin and Doiron draw upon a sociocultural perspective on literacy, as well as multiple and new literacies - with particular emphasis on transformative literacy - to frame their discussion on understandings of literacy within library contexts. They also consider participatory, collaborative, creative and distributive theories of learning, as well as informal learning practices of youth to explore the varied and interesting ways in which the libraries approach, facilitate and plan for the literacy and learning needs and aspirations of their communities. These theories of literacy and learning are used in the first three chapters as lenses to frame their examination of libraries. Chapter 1 'Libraries as Forces for Literacy and Learning' features a community library in Uganda; Chapter 2 'Building a Culture for Reading Through Libraries' focuses on a school library in Australia; and Chapter 3, 'Supporting Learning and Literacy through Libraries', presents a school library in Finland.

In Chapter 4, three additional conceptual frameworks - the library as a learning commons, the library as the community learning centre, and libraries as agents of social change - are introduced to situate discussions on the ways that libraries as institutions are understood. Paradoxically, a possible shortcoming of the book is the number of theories that are introduced to frame the discussions of the libraries. Although each theory is certainly relevant as a lens through which to view the library or context for which it is used, the flow of reading is at times interrupted by theoretical interjections. Fewer theories or a more cohesive, integrated framework of the theories would be more helpful for the reader. Chapter 4 also discusses the ways in which small libraries in Malaysia, Indonesia and Sweden serve as a 'learning commons'. Libraries that assume the role of community learning 
centres in Kenya, Argentina and Brazil are featured in Chapter 5, 'The Library as Community Learning Center', while a community library that has become an important agent of social change in the Canadian aboriginal community of Haida Gwaii is considered in Chapter 6, 'Libraries as Agents of Social Change'. Chapter 7, 'Mobile Libraries as Effective Solutions to Reading Access and Reading Promotion in Remote Communities', features a truck library in China; it also mentions some other remarkable mobile libraries that deliver books via buses, donkeys, elephants and even camels.

One of the strengths of this book is the attention given to the librarians and the immensely important (although often overlooked and underappreciated) role they play in the popularity and impact of the community library. Librarians from each of the featured libraries were invited to contribute profiles of their libraries to the book. These profiles provide rich descriptions not only of the collections, resources and programmes, but also of the particular needs and challenges, as well as innovations and achievements of their libraries. The rich insights and poignant observations of the librarians provide the reader with an understanding of each library's unique identity and how it responds to its specific community context. Asselin and Doiron acknowledge and reflect upon the commonalities as well as diversities of these libraries, contributing significantly to the global libraries discourse.

The book's presentation of, and reflections on the featured libraries' collections, activities, physical space and layout, and interrelationships with other institutions and organisations are other strong features of the book. These factors speak to the many ways that literacy and learning are embodied and actualised. Information provided on the libraries' collections, as well as observations on the collection needs of their libraries (such as the importance of and need for a comprehensive range of materials - fiction and non-fiction - in local languages, and materials relevant to local livelihoods), provides a sense of the kinds of literacies that are understood to be empowering for the communities. Also of importance is the discussion of how collections, and processes of selection of collections, can challenge the ways in which traditional libraries promoted and perpetuated hegemonic power structures through canonical privileging. In refreshing contrast to this oppressive model, Asselin and Doiron discuss how the Canadian aboriginal community of Haida Gwaii uses inclusive, democratic processes to select materials that celebrate and promote its cultural and linguistic heritage. However, Asselin and Doiron also acknowledge that collections acquisitions remain highly problematic in many parts of the world, especially with the reliance on 'donated books' by very poorly resourced libraries, especially in developing countries (e.g. Kenya).

Libraries are not merely buildings that house books, but dynamic learning centres that strive to meet the needs of each of their members, both as independent learners and as part of a community of learners. As such, the ways in which libraries are organised and experienced as places/spaces to facilitate and champion literacy and learning are given careful consideration in the book. Collaboration with other institutions and organisations is another common characteristic of the libraries discussed in this book. Relationships between, for example, national library associations (such as the Uganda Community Libraries Association), local schools, international foundations (such as the Finnish KONE Corporation Centennial Foundation) and Aboriginal Councils and Committees (Haida Gwaii) illustrate the fact that libraries do not exist in a vacuum, but are vibrant networking hubs that link communities with the larger world.

What libraries actually do in their communities is at the heart of this book, and the range of activities and programmes that libraries offer is staggering. The authors reflect thoughtfully on how the work done by these libraries and their librarians demonstrates, in practice, work towards 'the lofty goals of transforming their communities into ones that respect all members, provide equal access to their programmes/services and commit to equity and social justice for all' (137). Chapter 8 takes a broad look at 'Effective Practices in Reading Promotion and Literacy Development'. Asselin and Doiron identify five key areas - choice, opportunity, atmosphere, modelling and sharing - that support the development of 'a reading habit', and discuss examples of how libraries around the world have implemented them successfully. In this chapter, as well as throughout the book generally, Asselin and Doiron stress that what works 'best' is context-dependent, so they have chosen to use the term 'effective' to describe these practices. 
One central theme that runs throughout the book is the reconceptualisation of 'the library'. Asselin and Doiron argue that 'libraries are shifting from information repositories to community-led literacy, learning and cultural centers' (7). Each chapter draws the reader's attention to ways in which libraries evolve organically and holistically to meet the changing needs and demands of their communities, and also take the lead in bringing about transformative social change. In the final chapter of the book, Asselin and Doiron propose 'an ecological framework useful in the continuing development of small school and community libraries' (130). This framework provides a sound and useful lens through which to view, as well as to guide, the development of small libraries worldwide.

In sum, this book is an excellent resource and highly recommended for scholars and practitioners alike who are interested in the power, impact and transformative potential of small libraries. Asselin and Doiron have, indeed, achieved their aim of providing 'global perspectives on libraries' and made an impressive and valuable contribution to the area of libraries as a force of global change.

http://dx.doi.org/10.1080/01434632.2014.909114

Shelley Jones Aga Khan University - Institute for Educational Development,

East Africa

shelley.jones@aku.edu

(C) 2014 Shelley Jones 